\title{
Variability in Coronavirus Disease-2019 Case, Death, and Testing Rates in the United States and Worldwide
}

Ernst J. Schaefer, MD ${ }^{1,2, *}$, Andrew S. Geller, MS ${ }^{1}$, Latha Dulipsingh, $\mathrm{MD}^{3,4}$, Margaret R. Diffenderfer, $\mathrm{PhD}^{1}$, Jeffrey Wisotzkey, $\mathrm{PhD}^{5}$, and Steven B. Kleiboeker, $\mathrm{PhD}^{6}$

Short Title. COVID-19 Testing

${ }^{1}$ Boston Heart Diagnostics/Eurofins Scientific Network, Framingham, MA 01702, USA.

${ }^{2}$ Cardiovascular Nutrition Laboratory, Human Nutrition Research Center on Aging at Tufts University, and Tufts University School of Medicine, Boston, MA 02111, USA.

${ }^{3}$ Saint Francis Hospital, Trinity Health of New England, Hartford, CT 06105, USA.

${ }^{4}$ University of Connecticut School of Medicine, Farmington, CT 06032, USA.

${ }^{5}$ Diatherix Laboratories/Eurofins Scientific Network, Huntsville, AL 35806, USA.

${ }^{6}$ Viracor-Eurofins Clinical Diagnostics and Scientific Network, Lee's Summit, MO 64086, USA.

\section{*Corresponding author}

Ernst J. Schaefer, MD

Boston Heart Diagnostics, 200 Crossing Boulevard, Framingham, MA 01702, USA

Email: eschaefer@bostonheartdx.com; Telephone: (781) 258-1454; Fax (508) 302-8260

A preprint of a prior version of this manuscript was published as doi:medRxiv preprint;

https://doi.org/10.1101/2020.10.13.20172957. The data has now been updated as of November 28, 2020. 
medRxiv preprint doi: https://doi.org/10.1101/2020.10.13.20172957; this version posted December 31, 2020. The copyright holder for this preprint (which was not certified by peer review) is the author/funder, who has granted medRxiv a license to display the preprint in perpetuity.

It is made available under a CC-BY-ND 4.0 International license .

\begin{abstract}
Severe acute respiratory syndrome coronavirus-2 (SARS-CoV-2) infection has been associated with a worldwide pandemic. We assessed data as of November 25, 2020 from our combined laboratories and as reported for states in the United States (US) and countries for case, death, and testing rates per million to determine causes of rate differences. SARS-CoV-2 naso-pharyngeal (NP) RNA testing in 1,179,912 subjects in 47 states (39 of which with $>100$ cases) are reported, with a mean $9.3 \%$ positive rate, comparable to the $7.0 \%$ rate reported nationwide. In 91 previously positive (2-4 weeks) subjects, NP swab testing was twice as likely to be positive (58.6\%) as saliva samples $(21.5 \%)$. We also documented that NP swabs could remain positive for 6 weeks or longer. Our positive rates per state agreed reasonably well with reported national data $(\mathrm{r}=0.609, P<0.0001)$. The highest US case rates per million were in the midwest; the highest death and testing rates were in the northeast. Of 47 countries, the highest case, death, and testing rates per million were mainly in Europe and the Americas, with the lowest rates in Asia. Correlations between case and death rates and case and testing rates were very different between states (0.076 and -0.093 , respectively) and countries (0.763 and 0.600 , respectively). In conclusion, outpatient saliva testing was not as sensitive as NP testing for detection, and the marked variability in case and death rates was most likely due to differences in public health measures, viral and human genetic differences and age of cases, rather than due to differences in testing rates.
\end{abstract}

Key Words. SARS-CoV-2, COVID-19, swab RNA testing 
medRxiv preprint doi: https://doi.org/10.1101/2020.10.13.20172957; this version posted December 31, 2020. The copyright holder for this preprint (which was not certified by peer review) is the author/funder, who has granted medRxiv a license to display the preprint in perpetuity.

It is made available under a CC-BY-ND 4.0 International license .

\section{Abbreviations}

CDC, Centers for Disease Control and Prevention

COVID-19, coronavirus disease-2019

EUA, emergency use authorization

FDA, Food and Drug Administration

$\mathrm{N}$ gene, nucleocapsid gene

NP, naso-pharyngeal

$\mathrm{OP}$, oro-pharyngeal

PCR, polymerase chain reaction

RT-PCR, reverse transcriptase polymerase chain reaction

SARS-CoV-2, severe acute respiratory syndrome coronavirus-2

S gene, spike glycoprotein gene 


\section{INTRODUCTION}

Coronavirus disease-2019 (COVID-19) is caused by the severe acute respiratory syndrome coronavirus-2 (SARS-CoV-2) associated with a worldwide pandemic. The diagnosis is made by SARSCoV-2 RNA detection in naso-pharyngeal (NP) swabs, nasal swabs, oro-pharyngeal (OP) swabs, or saliva. ${ }^{1-4}$ The greatest number of deaths/million in the population has been reported in the northeastern United States. Up to $50 \%$ of SARS-CoV-2 positive patients can remain symptomatic; however, such individuals can spread infections. ${ }^{5-7}$ The average onset of symptoms after infection is about 5 days (range 2-14 days). COVID-19 fatality is substantially higher in the elderly and in those with cardiovascular disease, diabetes, obesity, hypertension, and lung disease.

COVID-19 disease symptoms include fever, fatigue, cough, loss of smell and taste, gastrointestinal symptoms, and shortness of breath. The virus spreads between people mainly via respiratory droplets. Complications include severe acute respiratory syndrome and potentially death from overwhelming infection and inflammation. ${ }^{1-4}$ While testing is critical for diagnosis, public health measures (e.g. face masks, social distancing and quarantining, hand washing, and contact tracing) are critical for prevention of new cases even after widespread vaccinations becomes available. Subjects that are positive for SARS-CoV-2 RNA based on NP swabs may not have transmissible virus over time, but may have only viral fragments in their nasal passages. ${ }^{7}$ Our goals were to assess data obtained from over a million SARS-CoV-2 RNA tests performed in our respective laboratories, as well as available US and worldwide data, in terms of cases, deaths, and testing per million in the population, in order to examine potential causes for the large rate differences observed between states and countries. 


\section{METHODS}

\section{Populations studied}

A total of $1,179,912$ subjects $(58.2 \%$ female; age range $1-101$ years; median [IQR] age 49.0 [35.0-6.0] years; $18.2 \% \geq 65$ years of age) were assessed in physician offices, clinics, and hospitals. These subjects had NP, OP, or nasal swab samples collected by healthcare providers at various sites throughout the United States, placed in viral transport media, and submitted by overnight express courier service for SARS-CoV-2 RNA detection to Boston Heart Diagnostics (Framingham, MA) beginning on April 17, 2020, Diatherix (Huntsville, AL) beginning on March 16, 2020, and/or Viracor (Lee’s Summit, MO) beginning on March 13, 2020. For this analysis, data assessment was ended as of November 1, 2020. Table 1 presents data from hospitals, clinic sites, and healthcare provider offices in 39 states with more than 100 results for samples sent to these laboratories. For this research, patient data were extracted from medical records without name or identification number and were analyzed as anonymized data, determined exempt from institutional review board approval by Advarra Institutional Review Board (Columbia, MD). In our view, this research is exempted from requirement for human institutional review board approval as per exemption 4, as listed at https://grants.nih.gov/policy/ humansubjects.htm and at the open education resource (OER) website for research involving human subjects. This exemption "involves the collection or study of data or specimens if publicly available or recorded such that subjects cannot be identified”. We had this designation and our research reviewed by the Advarra Institutional Review Board (Columbia, MD) and their determination was that "had the request for exempt determination been submitted prior to initiation of research activities, the research would have met the criteria for exemption from institutional review board review under 45 CFR 46.104(d). Therefore, they agreed that this research did not require institutional review board approval.

We also carried out a paired NP swab and saliva sample study, where we collected samples from previously positive subjects ( $\mathrm{n}=91$, mean age 53 years, $53 \%$ female) using an approved human institutional review board protocol (Trinity Health of New England, Hartford, CT); informed written consent was obtained from each subject. These subjects had all been positive 2-4 weeks earlier for SARS- 
medRxiv preprint doi: https://doi.org/10.1101/2020.10.13.20172957; this version posted December 31, 2020. The copyright holder for this preprint (which was not certified by peer review) is the author/funder, who has granted medRxiv a license to display the preprint in perpetuity.

It is made available under a CC-BY-ND 4.0 International license .

CoV-2 RNA based on NP swabs. The saliva was collected in viral transport media using kits obtained from Strategic Laboratory Partners (Nashville, TN).

To compare our own primary data with data from the general population, we first accessed data as of September 1, 2020 and then subsequently on November 25, 2020 from the Centers for Disease Control and Prevention (CDC) website (https://www.cdc.gov/covid-data-tracker/index.html\#testing), as well as the website https://www.worldometers.info/coronavirus/?, which uses a large number of data bases. For worldwide country data, we accessed the website https://www.worldometers.info/coronavirus/? and the World Health Organization website https://www.covid19.who.int/ on September 1, 2020 and again on November 25,2020 . On the latter date, there were $60,559,841$ cases (7,769/million) and $1,423,530$ deaths (183/million) worldwide. We specifically examined data for all countries with populations $>50$ million, as well as other selected countries. This analysis included 47 countries: 13 in Asia and Oceania; 11 in Europe; 5 in North America; 7 in South America; 7 in the Middle East; and 4 in Africa (Table 2).

\section{SARS-CoV-2 viral detection}

Detection of SARS-CoV-2 RNA in NP, OP, nasal swabs or saliva was performed using polymerase chain reaction (PCR) methods. As previously described, the Viracor assay using a reverse transcriptase PCR and TaqMan chemistry, targeted two regions of the SARS-CoV-2 nucleo-capsid (N) gene. ${ }^{8}$ The Boston Heart Diagnostics SARS-CoV-2 RNA assay was very similar to the Viracor assay except that this assay used Thermo-Fisher TaqPath COVID-19 Combo kits (Waltham, MA) and targeted a region in the $\mathrm{N}$ gene, a region in the spike (S) glycoprotein gene, and a region in the ORF1 gene. For both assays, a positive value was defined as detection of SARS-COV-2 RNA at a cycle threshold $\leq 37$ cycles. The Diatherix assay was based on nested, end-point PCR technology that allowed for SARS-CoV2 RNA detection through target enrichment and amplification. All assays have received emergency use authorization from the Food and Drug Administration. The sensitivity and specificity of these assays compared in known positive and negative subjects was found to be $>95 \%$. 
medRxiv preprint doi: https://doi.org/10.1101/2020.10.13.20172957; this version posted December 31, 2020. The copyright holder for this preprint (which was not certified by peer review) is the author/funder, who has granted medRxiv a license to display the preprint in perpetuity.

It is made available under a CC-BY-ND 4.0 International license.

\section{Statistical analysis}

All statistical analyses were performed using R software, version 3.6.0 (R Foundation, Vienna, Austria) for comparisons between rates, and the statistical significance of differences between groups was assess using the nonparametric Kruskal-Wallis method. Pearson correlation analysis was performed. 


\section{RESULTS}

\section{United States data}

As shown in Table 1, of 1,179,912 subjects having NP, OP, or nasal swabs done between March 13 and November 1, 2020 at various sites throughout the United States, the mean positive rate was 9.3\%. When we first tabulated these data on June 1, 2020, New York State had by far the highest percentage of positive subjects (43.5\%); this rate decreased to $4.3 \%$, when we included a total of 213,926 tests, mainly done for health screening and for nursing home residents and employees. In our total study population, $18.2 \%$ were $\geq 65$ years of age, of whom $6.9 \%$ were positive compared to $10.5 \%$ in the $<65$-year age group. Therefore, in the population we tested, older people did not have a higher positivity rate; in fact, it was lower $(P<0.0001)$, even though it has been well documented that elderly subjects have a significantly higher case fatality rate than younger subjects.

We noted a significant correlation for the percentage of positives $(\mathrm{r}=0.609, P<0.0001)$ between our data and the CDC state-wide data for the 39 states where we had >100 cases/state (Table 1).

As of November 25, 2020, based on CDC data, the top ten states in the United States for cases/million (all >50,000/million) were, in order, 1) North Dakota, 2) South Dakota, 3) Iowa, 4) Wisconsin, 5) Nebraska, 6) Utah, 7) Montana, 8) Illinois, 9) Kansas, and 10) Minnesota. In contrast, the top ten states in terms of deaths/million were 1) New Jersey, 2) New York, 3) Massachusetts, 4) Connecticut, 5) Louisiana, 6) Mississippi, 7) Rhode Island, 8) North Dakota, 9) Illinois, and 10) South Dakota. In terms of testing per 1 million, the top ten states were 1) Rhode Island, 2) Massachusetts, 3) New York, 4) Connecticut, 5) Illinois, 6) Louisiana, 7) Maryland, 8) New Mexico, 9) Minnesota, and 10) 6) Mississippi, 7) Rhode Island, 8) North Dakota, 9) Illinois, and 10) New Jersey.

The ten lowest states in terms of cases/million were 1) Oregon, 2) Washington, 3) West Virginia, 4) Virginia, 5) Pennsylvania, 6) California, 7) Connecticut, 8) Massachusetts, 9) Maryland, and 10) Ohio (Table 1). Similarly, the ten lowest states in terms of deaths/million were 1) Oregon, 2) Utah, 3) Washington, 4) Wyoming, 5) Oklahoma, 6) Kentucky, 7) Virginia, 8) California, 9) North Carolina, and 
medRxiv preprint doi: https://doi.org/10.1101/2020.10.13.20172957; this version posted December 31, 2020. The copyright holder for this preprint (which was not certified by peer review) is the author/funder, who has granted medRxiv a license to display the preprint in perpetuity.

It is made available under a CC-BY-ND 4.0 International license .

10) Idaho. The ten lowest states in terms of tests/million were 1) Oregon, 2) Pennsylvania, 3) Kansas, 4)

Colorado, 5) Alabama, 6) Arizona, 7) South Dakota, 8) Washington, 9) Idaho, and 10) Texas.

Figure 1 shows the relationship between death and case rates per million by state (Panel A), as

well as the relationship between the testing rate and the case rate (Panel B), both on a linear scale. These data from the CDC are based on 39,140 cases/million, 806 deaths/million and 559,370 tests/million in the US population. As can be clearly seen, the northeastern states of New Jersey, New York, Massachusetts, Connecticut, and Rhode Island had very high death rates per case. Intermediate mortality per case were observed in the southern states and the midwestern states. The lowest mortality per case were seen in the western states, especially Oregon, Utah, Washington, and Wyoming. As of September 1, 2020, the overall correlation, using Pearson correlation coefficient analysis, between deaths/million and cases/million was 0.473 ( $P<0.0001)$; between tests/million and cases/million, it was $0.398(P<0.0001) .{ }^{9}$ By November 25, 2020, the correlations had decreased significantly to 0.076 and -0.093 , respectively (Figure 1). In our view, these changes relate to more testing and less population public health measures. The states where the governors introduced early and constant public health measures had the lowest case and death rates, and the converse was also true.

\section{Paired NP swab and saliva data}

In the paired analysis examining positivity rates for NP swabs and saliva samples in 91 previously positive subjects, we noted that $58.6 \%$ of subjects were still positive based on NP swabs, but only $21.5 \%$ were positive based on saliva collection. These differences were statistically significant $P<0.01)$. We also documented that NP swabs could remain positive for 6 weeks or longer in this analysis in some cases.

\section{Worldwide data}

Data on the relationship between deaths/million and cases/million and between tests/million and cases/million are shown in Figure 2. These data are plotted on a log scale because of the marked variability between countries. As of September 1, 2020, the correlation between cases/million and 
deaths/million $(0.488, P<0.0001)$ was similar to what we observed for the US states, as were the correlation between cases/million and tests/million $(0.395 ; P<0.0001)$. However, as of November 25, 2020, the correlations worldwide had moved in the opposite direction. The correlations between cases/million and deaths/million had increased to $0.763(P<0.0001)$ and those between cases/million and tests/million had increased to $0.600(P<0.0001)$.

As of November 25, 2020, as shown in Table 2, the top ten countries for cases/million in order were: 1) Belgium, 2) Qatar, 3) United States, 4) Panama, 5) Israel, 6) Spain, 7) France, 8) Argentina, 9) Brazil, and 10) Peru. The top ten countries in terms of deaths/million in order were: 1) Belgium, 2) Peru, 3) Spain, 4) Italy, 5) United Kingdom, 6) Argentina, 7) United States, 8) Brazil, 9) Mexico, and 10) Chile. In terms of testing per 1 million, the top countries in order were: 1) United Kingdom, 2) Israel, 3) United States, 4) Russia, 5) Belgium, 6) Spain, 7) Norway, 8) Italy, 9) Finland, and 10) Germany.

The ten countries with the lowest cases/million in order were: 1) Vietnam, 2) Thailand, 3) China, 4) Nigeria, 5) New Zealand, 6) South Korea, 7) Ethiopia, 8) Japan, 9) Australia, and 10) Myanmar. Similarly, the ten countries with the lowest deaths/million in order were: 1) Vietnam, 2) Thailand, 3) China, 4) New Zealand, 5) Nigeria, 6) South Korea, 7) Ethiopia, 8) Japan, 9) Kenya, and 10) Myanmar. The ten countries with the lowest tests/million in order were: 1) Nigeria, 2) Egypt, 3) Ethiopia, 4) Vietnam, 5) Thailand, 6) Bangladesh, 7) Myanmar, 8) Indonesia, 9) Mexico, and 10) Japan. 
medRxiv preprint doi: https://doi.org/10.1101/2020.10.13.20172957; this version posted December 31, 2020. The copyright holder for this preprint (which was not certified by peer review) is the author/funder, who has granted medRxiv a license to display the preprint in perpetuity.

It is made available under a CC-BY-ND 4.0 International license .

\section{DISCUSSION}

The rapid spread of SARS-CoV-2 viral infection has been in large part due to its very contagious nature and the fact that many infected people are asymptomatic. Although the pandemic started in China, its spread there, as well as in other countries in Asia, has been very well controlled; and the case and death rates per million in these countries have been very low. One cannot attribute this excellent infection control to testing, but rather to outstanding public health measures (use of face masks, isolation, contact tracing, and social distancing). Even in countries such as India, Bangladesh, the Philippines, and Australia with >1,000 cases/million, death rates have been low. In contrast, subjects in Europe, North America, South America, and parts of the Middle East have fared far worse with much higher case and death rates, despite a large amount of testing. In the midwestern and southern states of the United States case rates have been very high, while death rates have been the highest in the world in the northeastern states, despite a lot of testing. This latter finding may well have been due to the high infection rate early on in the United States pandemic in long-term care facilities in the northeast. Recently, there has been a large decrease in the correlation between cases and testing in the United States, indicating a lot of testing, but lack of public health measures, especially in younger people participating in demonstrations and political rallies. ${ }^{9}$

Rates in the United States and Brazil were comparable in cases and deaths, due in our view to very limited public health measures and lack of central government leadership in both countries. In contrast, Japan, South Korea, China, and Thailand had much lower rates, presumably due to significantly better public health measures. Many European countries had case rates lower than the United States, but comparable death rates. These differences could relate to the age of subjects becoming infected. The importance of public health measures may best be exemplified by comparing Sweden, which did not introduce such measures, to its neighbors Norway and Finland, which did introduce such measures. Sweden had case and death rates that were much higher than rates observed in Norway and Finland. These marked differences occurred despite the fact that these countries had fairly comparable testing rates. 
medRxiv preprint doi: https://doi.org/10.1101/2020.10.13.20172957; this version posted December 31, 2020. The copyright holder for this preprint (which was not certified by peer review) is the author/funder, who has granted medRxiv a license to display the preprint in perpetuity.

It is made available under a CC-BY-ND 4.0 International license .

There may be other potential causes of the large variability in case and death rates between countries. One such possibility is mutations in the virus. The D614G amino acid substitution in the $\mathrm{S}$ glycoprotein as well as other variants encoded by the SARS-CoV-2 S gene has been reported to result in forms of the virus that may be more infective and virulent than the original Wuhan strain. ${ }^{10-16}$ The D614G variant has been found in over $90 \%$ of United States strains. Another possibility is human genetic variation. Genome-wide association studies have identified a 3p21.31 DNA locus as being associated with a significant 1.77 -fold increased risk for respiratory failure in hospitalized COVID-19 patients. ${ }^{17}$ This genetic variant, apparently inherited from Neanderthals, is not present in subjects indigenous to China, Japan, or Sub-Saharan Africa, but has a frequency of $\sim 5-8 \%$ in North America and western Europe and $\sim 20 \%$ in India. ${ }^{18}$ Therefore, both viral and human genetic variation may play a role in country differences with regard to SARS-CoV-2 cases and mortality rates. Another potential reason for mortality differences is the age of infected people, since it is well known the elderly have much higher SARS-CoV-2 mortality rates than the young. However, it is most likely that the efficiency of public health measures accounts for most of the variability in case and death rates per million in the population. ${ }^{19,20}$

Recently, there has been a significant increase in SARS-CoV-2 RNA testing in the United States in an effort to control the pandemic in the absence of vaccines. There have also been efforts to find easier ways to carry out such testing. Data from Yale New Haven Medical Center indicated that self-collected saliva samples yielded similar or better results than did NP swabs in terms of detecting SARS-CoV-2 positive hospitalized patients based on 44 paired samples. ${ }^{3}$ However, our data in previously positive outpatients indicated that saliva analysis only identified about half as many positive cases as compared to NP swab analysis. Saliva testing is being widely used. 
medRxiv preprint doi: https://doi.org/10.1101/2020.10.13.20172957; this version posted December 31, 2020. The copyright holder for this preprint (which was not certified by peer review) is the author/funder, who has granted medRxiv a license to display the preprint in perpetuity.

It is made available under a CC-BY-ND 4.0 International license .

\section{CONCLUSIONS}

Our data indicate that: 1) outpatient saliva testing is not as sensitive as NP testing; 2) the marked variability in case and death rates between states and countries is mainly due to difference in public health measures; 3) variations in SARS-CoV-2 viral genetics, human genetics, and age of populations getting infected may also play a role in rate differences; and 4) rate differences are least likely to be due differences in testing rates. Our overall data strongly support the benefits of public health measures in preventing spread of SARS-CoV-2 infection. In our view, the major reason for the very high case and mortality rates in the United States, as well as some other countries, has been the consistent lack of such measures, due to failures of central government and public agency leadership. 
medRxiv preprint doi: https://doi.org/10.1101/2020.10.13.20172957; this version posted December 31, 2020. The copyright holder for this preprint (which was not certified by peer review) is the author/funder, who has granted medRxiv a license to display the preprint in perpetuity.

It is made available under a CC-BY-ND 4.0 International license .

\section{Acknowledgements}

We thank the medical personnel and technical staff at each institution for their effort and commitment to SARS-CoV-2 testing. We also thank Shannon Foster of Viracor-Eurofins Clinical Diagnostics and Scientific Network for compiling all RNA data. All information was anonymized prior to data analysis.

All relevant ethical guidelines were followed in carrying out this research.

\section{Research Support and Disclosures}

Support for this research was received from Boston Heart Diagnostics, Viracor-Eurofins Clinical Diagnostics and Scientific Network, Diatherix, and Trinity Health of New England. No relevant conflicts of interest were identified, except that many authors are either full-time or part-time employees of reference laboratories that provide testing for healthcare providers [Boston Heart Diagnostics (EJS, ASG, MRD), Diatherix (JW), and Viracor-Eurofins Clinical Diagnostics (SBK)]. Boston Heart Diagnostics, Diatherix, and Viracor-Eurofins Clinical Diagnostics are part of the global network of Eurofins laboratories and the Eurofins Scientific Network with headquarters in Brussels, Belgium. No payments were received from any third party to influence the results of the research. 
medRxiv preprint doi: https://doi.org/10.1101/2020.10.13.20172957; this version posted December 31, 2020. The copyright holder for this preprint (which was not certified by peer review) is the author/funder, who has granted medRxiv a license to display the preprint in perpetuity.

It is made available under a CC-BY-ND 4.0 International license .

\section{REFERENCES}

1. Zhou X-L, Yang X-G, Wang B et al. A pneumonia outbreak associated with a new coronavirus of probable bat origin. Nature 2020;579:270-273 doi:10.1038/s41586-020-2012-7 [published Online First: 3 February 2020].

2. Zhu N, Zhang D, Wang W et al. A novel coronavirus from patients with pneumonia in China, 2019. N Engl J Med 2020;382:727-733 doi:10.1056/NEJMoa2001017 [published Online First: 24 January 2020]/

3. Wylie AL, Fournier J, Casanovas-Massana A et al. Saliva or naopharyngeal swab specimens for detection of SARS-CoV-2. N Engl J Med 2020;383:1283-1286 doi:10.1056/NEJMc2016359

[published Online First: 28 August 2020].

4. Wiersinga WJ, Rhodes A, Cheng AC, Peacock SJ, Prescott HC. Pathophysiology, transmission, diagnosis, and treatment of Coronavirus Disease 2019 (COVID-19): A review. JAMA 2020;324:782793 doi:10.1001/jama.2020.12839.

5. Rothe C, Schunk M, Sothmann P et al. Transmission of 2019-nCoV Infection from an asymptomatic contact in Germany. N Engl J Med 2020;382:970-971 doi:10.1056/NEJMc2001468 [published Online First: 30 January 2020].

6. Mizumoto K, Kagaya K, Zarebski K, Chowell G. Estimating the asymptomatic proportion of coronavirus disease 2019 (COVID-19) cases on board the Diamond Princess cruise ship, Yokohama, Japan, 2020. Euro Surveill 2020;25:2000180 doi:10.2807/1560-7917.ES.2020.25.10.2000180.

7. To KK, Tsang OT, Leung WS et al. Temporal profiles of viral load in posterior oropharyngeal saliva samples and serum antibody responses during infection by SARS-CoV-2: an observational cohort study. Lancet Infect Dis 2020:20:565-574 doi:10.1016/S1473-3099(20)30196-1 [published Online First: 23 March 2020].

8. Kleiboeker S, Cowden S, Grantham J, Nutt J, Tyler A, Berg A, Altrich M. SARS-CoV-2 viral load assessment in respiratory samples. J Clin Virol 2020;129:104439 doi:10.1016/j.jcv.2020.104439 [published Online First: 19 May 2020]. 
medRxiv preprint doi: https://doi.org/10.1101/2020.10.13.20172957; this version posted December 31, 2020. The copyright holder for this preprint (which was not certified by peer review) is the author/funder, who has granted medRxiv a license to display the preprint in perpetuity.

It is made available under a CC-BY-ND 4.0 International license .

9. Schaefer EJ, Geller AS, Diffenderfer MR, Dulipsingh L, Wisotzkey J, Kleiboeker SB. Coronavirus disease-2019 case, death, and testing rates in the United States and worldwide: Primary data and review. medRxiv preprint Online First 14 October 2020. doi.org/10.1101/2020.10.13.20172957

10. Koyama T, Weeraratne D, Snowdon JL, Parida L. Emergence of drift variants that may affect COVID-19 vaccine development and antibody treatment. Pathogens 2020;9:324

doi:10.3390/pathogens9050324.

11. Zhang L, Jackson CB, Mou H et al. The D614G mutation in the SARS-CoV-2 spike protein reduces S1 shedding and increases infectivity. bioRxiv Published Online First: 12 June 2020. doi:10.1101/2020.06.12.148726

12. Daniloski Z, Guo X, Sanjana NE. The D614G mutation in SARS-CoV-2 spike increases transduction of multiple human cell types. bioRxiv Published Online First: 15 June 2020. doi:10.1101/2020.06.14.151357

13. Korber B, Fischer WM, Gnanakaran S et al. Tracking changes in SARS-CoV-2 spike: evidence that D614G increases infectivity of the COVID-19 virus. Cell 2020;182:812-827.e19 doi:10.1016/j.cell.2020.06.043 [Published Online First: 3 July 2020].

14. Hoque MN, Chaudhury A, Akanda MAM, Hossain MA, Islam MT Genomic diversity and evolution, diagnosis, prevention, and therapeutics of the pandemic COVID-19 disease. PeerJ 2020;8:e9689 doi:10.7717/peerj.9689.

15. Portelli S, Olshansky M, Rodrigues CHM, et al. Exploring the structural distribution of genetic variation in SARS-CoV-2 with the COVID-3D online resource. Nat Genet. 2020 Oct;52(10):999-1001. doi:10.1038/s41588-020-0693-3.

16. Van Dorp L, Richard D, Tan CCS et al. Nat Commun. No evidence for increased transmissibility from recurrent mutations in SARS-CoV-2. 2020 Nov 25;11(1):5986. doi: 10.1038/s41467-02019818-2.

17. Ellinghaus D, Degenhardt F, Bujanda L et al. Genome-wide association study of severe Covid-19 
medRxiv preprint doi: https://doi.org/10.1101/2020.10.13.20172957; this version posted December 31, 2020. The copyright holder for this preprint (which was not certified by peer review) is the author/funder, who has granted medRxiv a license to display the preprint in perpetuity. It is made available under a CC-BY-ND 4.0 International license .

with respiratory failure. N Engl J Med 2020;383:1522-1534 doi:10.1056/NEJMoa2020283 [published Online First: 17 June 2020].

18. Zeberg H, Pääbo S. The major genetic risk factor for severe COVID-19 is inherited from Neandertals. Nature 2020;587:610-612 doi:10.1038/s41586-020-2818-3 [published Online First: 30 September 2020].

19. Sharma R, Akhoury G. 2019-nCoV: a worldwide concern and facts. Virusdisease 2020; 31:1-8. doi: $10.1007 / \mathrm{s} 13337-020-00633-8$.

20. Bhagat S, Yadav N, Shah J, et al. Novel corona virus (COVID-19) pandemic: current status and possible strategies for detection and treatment of the disease. Expert Rev Anti Infect Ther Published Online First 7 December 2020. doi:10.1080/14787210.2021.1835469. 
medRxiv preprint doi: https://doi.org/10.1101/2020.10.13.20172957; this version posted December 31, 2020. The copyright holder for this preprint (which was not certified by peer review) is the author/funder, who has granted medRxiv a license to display the preprint in perpetuity.

It is made available under a CC-BY-ND 4.0 International license.

\section{FIGURE LEGENDS}

FIGURE 1 COVID-19 death and testing rates relative to case rates in the United States as of November 25 2020. The reported cases of COVID-19 per 1 million people are presented by state versus the reported deaths due to COVID-19 (Panel A) and versus the reported tests for COVID-19 (Panel B). Red circles indicate states in the Northeast, green circles, states in the upper Midwest; purple circles, states in the lower Midwest; orange circles, states in the South; and blue circles, states in the West. Linear scales were used.

FIGURE 2 COVID-19 fatality and testing rates relative to case rates worldwide as of November 25, 2020. The reported cases of COVID-19 per 1 million people are presented by country versus the reported deaths due to COVID-19 (Panel A) and versus the confirmed tests for COVID-19 (Panel B). Blue circles represent Asia; gold circles, Europe; red circles, North America; orange circles, South America; purple circles, Africa; and green circles, the Middle East. Log scales were used. 
medRxiv preprint doi: https://doi.org/10.1101/2020.10.13.20172957; this version posted December 31, 2020. The copyright holder for this preprint (which was not certified by peer review) is the author/funder, who has granted medRxiv a license to display the preprint in perpetuity.

It is made available under a CC-BY-ND 4.0 International license .

TABLE 1 SARS-CoV-2 RNA positive rates by states with >100 tests (Eurofins testing)

\begin{tabular}{|c|c|c|c|c|c|c|}
\hline \multirow[b]{2}{*}{ State } & \multicolumn{4}{|c|}{ Centers for Disease Control and Prevention* } & \multicolumn{2}{|c|}{ 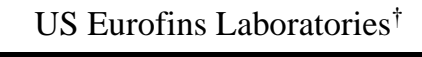 } \\
\hline & Cases/1 M & Deaths/1M & Tests/1M & $\%$ Positive & Tests Done & $\%$ Positive \\
\hline Alabama & 49,347 & 729 & 333,210 & $14.8 \%$ & 89,040 & $11.0 \%$ \\
\hline Arizona & 43,184 & 902 & 348,958 & $12.4 \%$ & 954 & $8.6 \%$ \\
\hline Arkansas & 50,575 & 807 & 589,831 & $8.6 \%$ & 17,529 & $7.9 \%$ \\
\hline California & 29,718 & 482 & 584,547 & $5.1 \%$ & 52.275 & $2.9 \%$ \\
\hline Colorado & 37,627 & 513 & 293,408 & $8.8 \%$ & 8,723 & $6.5 \%$ \\
\hline Connecticut & 30,615 & 1,382 & 862,624 & $3.5 \%$ & 565 & $3.5 \%$ \\
\hline Delaware & 34,484 & 782 & 422,132 & $8.2 \%$ & 5,784 & $4.9 \%$ \\
\hline Florida & 44,775 & 850 & 566,357 & $8.0 \%$ & 124,733 & $16.1 \%$ \\
\hline Georgia & 43,468 & 879 & 431,979 & $10.0 \%$ & 181,136 & $13.8 \%$ \\
\hline Idaho & 54,001 & 501 & 390,728 & $13.8 \%$ & - & - \\
\hline Illinois & 55,043 & 994 & 805,890 & $6.8 \%$ & 11,891 & $10.4 \%$ \\
\hline Indiana & 47,368 & 826 & 609,049 & $7.8 \%$ & 11,316 & $8.3 \%$ \\
\hline Iowa & 70,615 & 733 & 378,983 & $18.6 \%$ & 2,615 & $7.5 \%$ \\
\hline Kansas & 51,470 & 516 & 274,322 & $18.8 \%$ & 23,043 & $7.3 \%$ \\
\hline Kentucky & 40,075 & 427 & 624,592 & $6.4 \%$ & 43,881 & $9.0 \%$ \\
\hline Louisiana & 48,537 & 1,366 & 730,872 & $6.6 \%$ & 12,823 & $9.1 \%$ \\
\hline Maryland & 31,507 & 752 & 709,287 & $4.4 \%$ & 1,303 & $7.4 \%$ \\
\hline Massachusetts & 31,134 & 1,538 & $1,179,643$ & $2.6 \%$ & 2,838 & $8.0 \%$ \\
\hline Michigan & 35,290 & 918 & 683,096 & $5.2 \%$ & 29,680 & $10.2 \%$ \\
\hline Minnesota & 51,298 & 609 & 701,632 & $7.3 \%$ & - & - \\
\hline Mississippi & 47,004 & 1,264 & 432,712 & $10.9 \%$ & 4,271 & $20.2 \%$ \\
\hline Missouri & 49,400 & 657 & 518,632 & $9.5 \%$ & 71,684 & $3.5 \%$ \\
\hline Montana & 55,841 & 616 & 591,261 & $9.4 \%$ & - & - \\
\hline Nebraska & 62,074 & 506 & 373,945 & $16.5 \%$ & 11,4477 & $12.0 \%$ \\
\hline Nevada & 47,004 & 680 & 517,154 & $9.1 \%$ & - & - \\
\hline New Jersey & 37,042 & 1,920 & 656,070 & $5.6 \%$ & 2,846 & $7.7 \%$ \\
\hline New Mexico & 42,825 & 701 & 717,682 & $6.0 \%$ & - & - \\
\hline New York & 33,835 & 1,768 & 963,495 & $3.5 \%$ & 213,926 & $4.3 \%$ \\
\hline
\end{tabular}


medRxiv preprint doi: https://doi.org/10.1101/2020.10.13.20172957; this version posted December 31, 2020. The copyright holder for this preprint (which was not certified by peer review) is the author/funder, who has granted medRxiv a license to display the preprint in perpetuity.

It is made available under a CC-BY-ND 4.0 International license .

\begin{tabular}{|c|c|c|c|c|c|c|}
\hline \multirow[b]{2}{*}{ State } & \multicolumn{4}{|c|}{ Centers for Disease Control and Prevention* } & \multicolumn{2}{|c|}{ 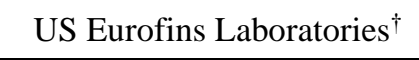 } \\
\hline & Cases/1 M & Deaths/1M & Tests/1M & $\%$ Positive & Tests Done & $\%$ Positive \\
\hline North Carolina & 33,038 & 490 & 482,971 & $6.8 \%$ & 74,880 & $7.2 \%$ \\
\hline North Dakota & 100,309 & 1,177 & 452,396 & $22.2 \%$ & - & - \\
\hline Ohio & 32,774 & 537 & 499,249 & $6.6 \%$ & 21,959 & $10.7 \%$ \\
\hline Oklahoma & 46,587 & 425 & 523,617 & $7.5 \%$ & 9,937 & $13.0 \%$ \\
\hline Oregon & 16,598 & 209 & 244,364 & $6.8 \%$ & 2,109 & $6.9 \%$ \\
\hline Pennsylvania & 26,636 & 804 & 271,595 & $9.8 \%$ & 11,377 & $4.1 \%$ \\
\hline Rhode Island & 49,385 & 1,260 & $1,408,680$ & $3.5 \%$ & - & - \\
\hline South Carolina & 40,963 & 838 & 504,948 & $8.1 \%$ & 23,931 & $12.9 \%$ \\
\hline South Dakota & 80,069 & 960 & 359,861 & $22.2 \%$ & 2,035 & $2.7 \%$ \\
\hline Tennessee & 51,599 & 662 & 639,014 & $8.1 \%$ & 69,473 & $10.2 \%$ \\
\hline Texas & 42,463 & 751 & 397,751 & $10.7 \%$ & 18,808 & $17.7 \%$ \\
\hline Utah & 57,363 & 260 & 615,503 & $9.3 \%$ & 1,609 & $5.3 \%$ \\
\hline Virginia & 26,817 & 472 & 433,495 & $6.2 \%$ & 5,675 & $9.5 \%$ \\
\hline Washington & 21,159 & 357 & 380,093 & $5.6 \%$ & 2,844 & $3.8 \%$ \\
\hline West Virginia & 24,652 & 397 & 602,108 & $4.1 \%$ & 1,537 & $4.2 \%$ \\
\hline Wisconsin & 64,327 & 556 & 429,329 & $15.0 \%$ & 2,638 & $5.8 \%$ \\
\hline Wyoming & 53,150 & 371 & 624,903 & $8.5 \%$ & 1,258 & $5.6 \%$ \\
\hline
\end{tabular}

Data as of November 25, 2020 with 39,140 cases, 806 deaths, and 559,340 tests/1M in the United States for an overall 7.0\% positive rate.

*Testing as reported on the following websites: https://www.cdc.gov/covid-data-tracker/index.html\#cases and www.worldometersinfo/coronavirus.

${ }^{\dagger}$ Eurofins data based on PCR testing of 1,179,912 subjects in 47 states (39 of which with >100 cases are reported above) had a mean $9.3 \%$ positive rate as of November $1^{\text {st }}, 2020$.

†Pearson correlation between total reported state positive rates and US Eurofins Laboratories positive rates was $r=0.609(P<0.001)$.

$1 \mathrm{M}, 1$ million people. 
medRxiv preprint doi: https://doi.org/10.1101/2020.10.13.20172957; this version posted December 31, 2020. The copyright holder for this preprint (which was not certified by peer review) is the author/funder, who has granted medRxiv a license to display the preprint in perpetuity.

It is made available under a CC-BY-ND 4.0 International license .

TABLE 2 SARS-CoV-2 cases, deaths, and testing per million in the population

\begin{tabular}{|c|c|c|c|c|c|}
\hline Country & Cases/1 M & Deaths/1M & Tests/1M & $\%$ Positive & $\begin{array}{c}\text { Case Fatality } \\
\text { Rate }\end{array}$ \\
\hline \multicolumn{6}{|c|}{ ASIA AND OCEANIA } \\
\hline India & 6,687 & 98 & 97,329 & $6.9 \%$ & $1.47 \%$ \\
\hline Philippines & 3,839 & 75 & 50,714 & $7.5 \%$ & $1.95 \%$ \\
\hline Indonesia & 1,863 & 59 & 19,899 & $9.4 \%$ & $3.17 \%$ \\
\hline Bangladesh & 2,747 & 39 & 16,306 & $16.8 \%$ & $1.42 \%$ \\
\hline Pakistan & 1,720 & 35 & 23,801 & $7.2 \%$ & $2.03 \%$ \\
\hline Australia & 1,087 & 35 & 383,755 & $0.3 \%$ & $3.22 \%$ \\
\hline Myanmar & 1,532 & 33 & 19,730 & $7.8 \%$ & $2.15 \%$ \\
\hline South Korea & 619 & 10 & 57,839 & $1.1 \%$ & $1.64 \%$ \\
\hline Japan & 1,072 & 16 & 26,373 & $4.1 \%$ & $1.49 \%$ \\
\hline New Zealand & 408 & 5 & 248,599 & $0.2 \%$ & $1.23 \%$ \\
\hline China & 60 & 3 & 111,163 & $0.05 \%$ & $5.00 \%$ \\
\hline Thailand & 54 & 0.9 & 13,995 & $0.4 \%$ & $1.67 \%$ \\
\hline Vietnam & 14 & 0.4 & 13,712 & $0.1 \%$ & $2.86 \%$ \\
\hline \multicolumn{6}{|l|}{ EUROPE } \\
\hline Belgium & 48,390 & 1,373 & 492,764 & $9.8 \%$ & $2.84 \%$ \\
\hline Spain & 34,700 & 942 & 468,697 & $7.4 \%$ & $7.40 \%$ \\
\hline Italy & 24,507 & 861 & 346,808 & $7.1 \%$ & $3.51 \%$ \\
\hline United Kingdom & 22,887 & 831 & 615,308 & $3.7 \%$ & $3.60 \%$ \\
\hline France & 33,217 & 775 & 307,643 & $10.8 \%$ & $2.22 \%$ \\
\hline Sweden & 22,768 & 647 & 287,225 & $7.9 \%$ & $2.84 \%$ \\
\hline Ukraine & 15,171 & 263 & 97,269 & $15.6 \%$ & $1.73 \%$ \\
\hline Russia & 14,815 & 257 & 504,934 & $1.7 \%$ & $2.93 \%$ \\
\hline Germany & 11,678 & 182 & 315,370 & $3.7 \%$ & $1.56 \%$ \\
\hline Finland & 4,086 & 70 & 335,210 & $1.2 \%$ & $1.71 \%$ \\
\hline Norway & 6,250 & 58 & 401,259 & $1.6 \%$ & $0.93 \%$ \\
\hline \multicolumn{6}{|c|}{ NORTH AMERICA } \\
\hline United States & 39,140 & 806 & 559,340 & $7.0 \%$ & $2.06 \%$ \\
\hline
\end{tabular}


medRxiv preprint doi: https://doi.org/10.1101/2020.10.13.20172957; this version posted December 31, 2020. The copyright holder for this preprint (which was not certified by peer review) is the author/funder, who has granted medRxiv a license to display the preprint in perpetuity.

It is made available under a CC-BY-ND 4.0 International license .

\begin{tabular}{|c|c|c|c|c|c|}
\hline Country & Cases/1 M & Deaths/1M & Tests/1M & $\%$ Positive & $\begin{array}{c}\text { Case Fatality } \\
\text { Rate }\end{array}$ \\
\hline Mexico & 8,188 & 794 & 21,186 & $38.6 \%$ & $9.70 \%$ \\
\hline Panama & 36,145 & 688 & 195,453 & $18.5 \%$ & $1.91 \%$ \\
\hline Canada & 9,121 & 309 & 291,154 & $3.1 \%$ & $3.39 \%$ \\
\hline Guatemala & 6,649 & 228 & 28,759 & $23.1 \%$ & $3.43 \%$ \\
\hline \multicolumn{6}{|c|}{ SOUTH AMERICA } \\
\hline Peru & 28,727 & 1,076 & 148,649 & $19.3 \%$ & $3.75 \%$ \\
\hline Argentina & 30,462 & 825 & 81,851 & $37.2 \%$ & $2.71 \%$ \\
\hline Brazil & 28,747 & 798 & 102,738 & $28.0 \%$ & $2.78 \%$ \\
\hline Chile & 28,365 & 789 & 267,891 & $10.6 \%$ & $2.78 \%$ \\
\hline Ecuador & 10,504 & 747 & 35,289 & $29.8 \%$ & $7.11 \%$ \\
\hline Bolivia & 12,089 & 744 & 28,423 & $42.5 \%$ & $6.15 \%$ \\
\hline Columbia & 24,701 & 698 & 120,080 & $20.6 \%$ & $2.80 \%$ \\
\hline \multicolumn{6}{|c|}{ MIDDLE EAST } \\
\hline Iran & 10,594 & 547 & 70,045 & $15.1 \%$ & $5.16 \%$ \\
\hline Israel & 36,061 & 307 & 597,111 & $6.0 \%$ & $0.85 \%$ \\
\hline Iraq & 13,362 & 298 & 82,492 & $16.2 \%$ & $2.23 \%$ \\
\hline Saudi Arabia & 10,165 & 166 & 268,395 & $3.8 \%$ & $1.63 \%$ \\
\hline Turkey & 5,522 & 152 & 209,366 & $2.6 \%$ & $2.75 \%$ \\
\hline Qatar & 47,268 & 83 & 348,678 & $13.6 \%$ & $0.18 \%$ \\
\hline Egypt & 1,103 & 64 & 9,700 & $11.4 \%$ & $5.80 \%$ \\
\hline \multicolumn{6}{|l|}{ AFRICA } \\
\hline South Africa & 12,956 & 354 & 89,347 & $14.5 \%$ & $2.73 \%$ \\
\hline Kenya & 1,462 & 26 & 15,771 & $9.3 \%$ & $1.78 \%$ \\
\hline Ethiopia & 923 & 14 & 13,869 & $6.7 \%$ & $1.52 \%$ \\
\hline Nigeria & 320 & 6 & 3,599 & $8.9 \%$ & $1.88 \%$ \\
\hline
\end{tabular}

As of November 25, 2020, there were 60,559,841 cases (7,769/million) and 1,423,530 deaths (183/million) worldwide.

Data as reported on the following websites: https://www.who.org and www.worldometersinfo/coronavirus.

Countries are grouped by continents and ranked according to number of deaths/million. 
A medRxiv preprint doi: https://doi.org/10.1101/2020.10.13.20172957; this version posted December 31, 2020. The copyright holder for this

preprint (which wps not certified by peer review) is the author/funder, who has granted medRxiv a license to display the prepkintipperpgtuity.
In

\begin{tabular}{ll|l}
$\bar{\sigma}$ & 1,500 & OMA \\
อे & & OCT
\end{tabular}

MS ORI

ND

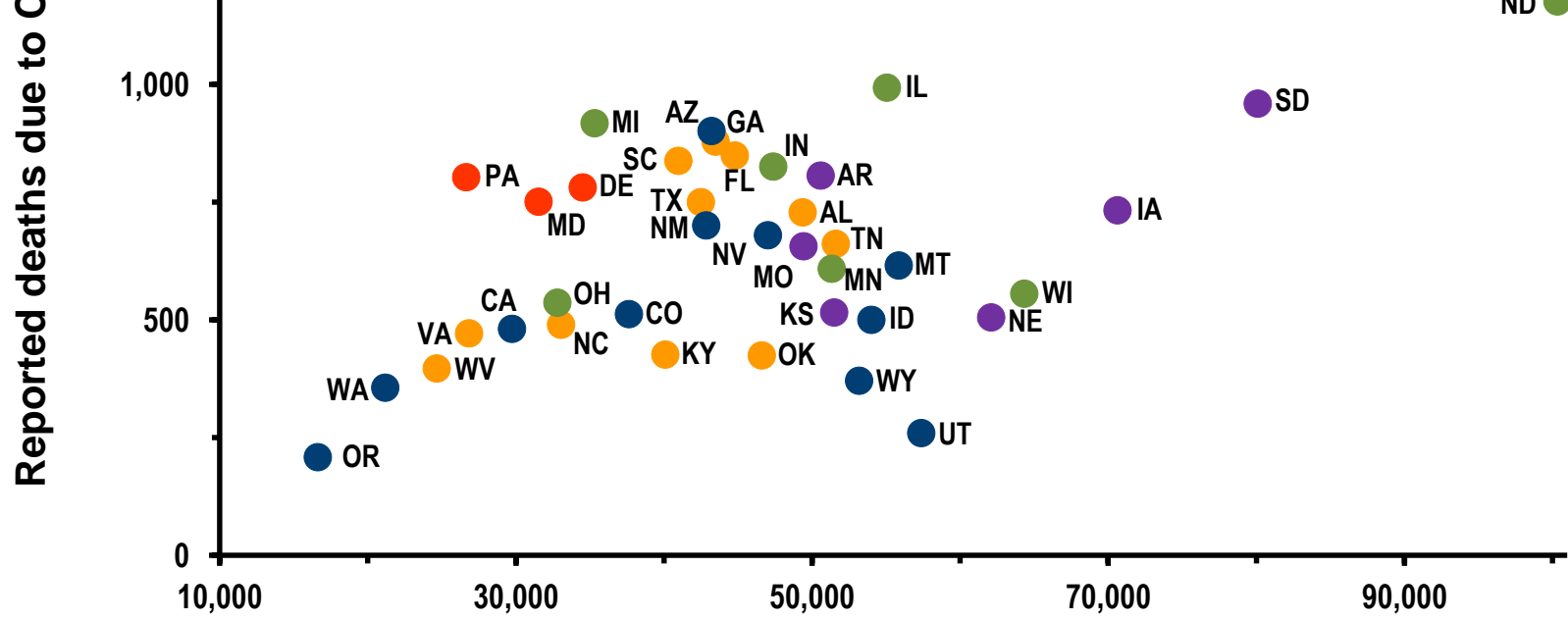

B

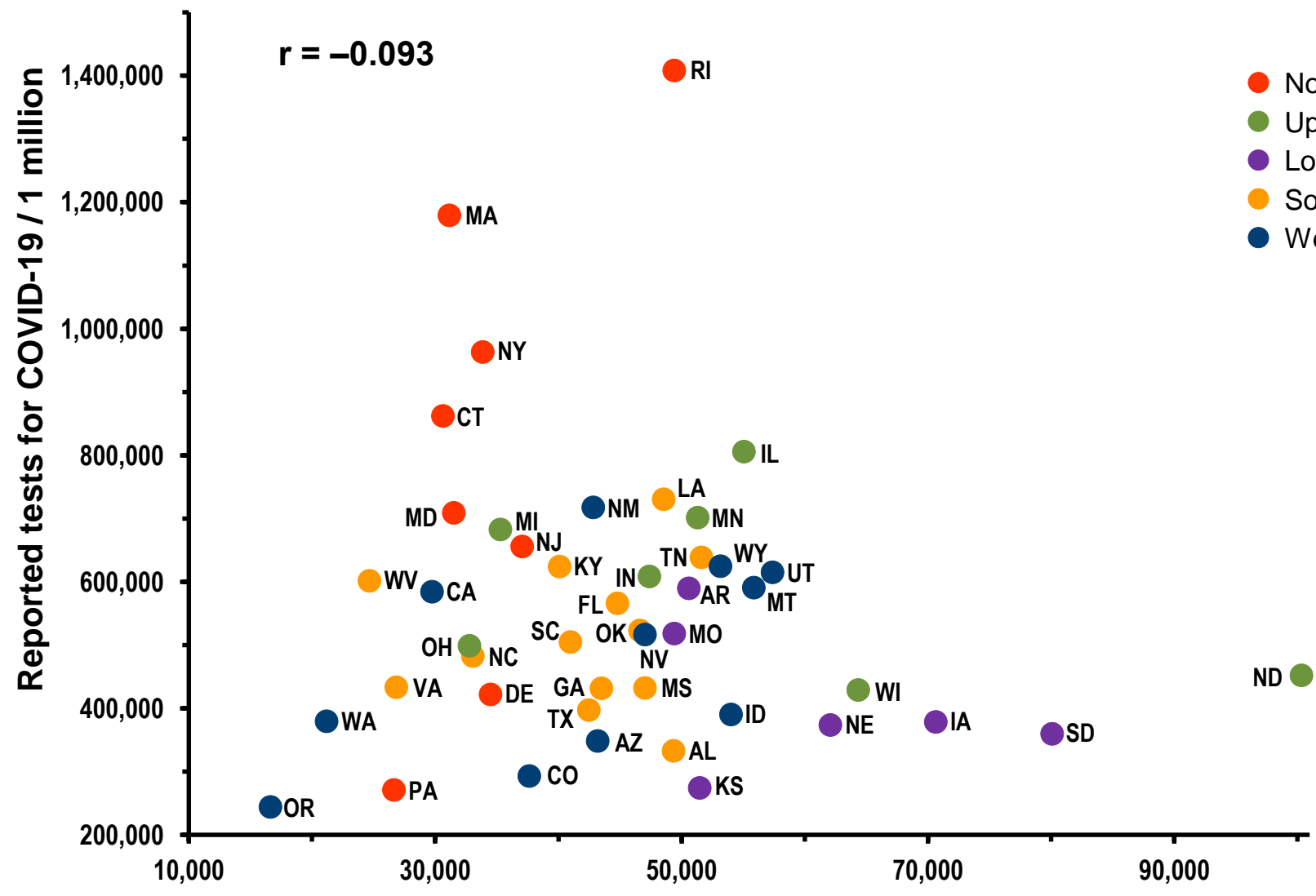

Reported cases of COVID-19 / 1 million

FIGURE 1 COVID-19 death and testing rates relative to case rates in the United States as of November 25, 2020. The reported cases of COVID-19 per 1 million people are presented by state versus the reported deaths due to COVID-19 (Panel A) and versus the reported tests for COVID-19 (Panel B). Red circles indicate states in the Northeast; green circles, states in the upper Midwest; purple circles, states in the lower Midwest; orange circles, states in the South; and blue circles, states in the West. Linear scales were used. 
medRxiv preprint doi: https://doi.org/10.1101/2020.10.13.20172957; this version posted December 31,2020. The copyright holder for this A preprint (which _was not certified by peer review) is the author/funder, who has granted medRxiv a license to display the preprint in perpetuity.

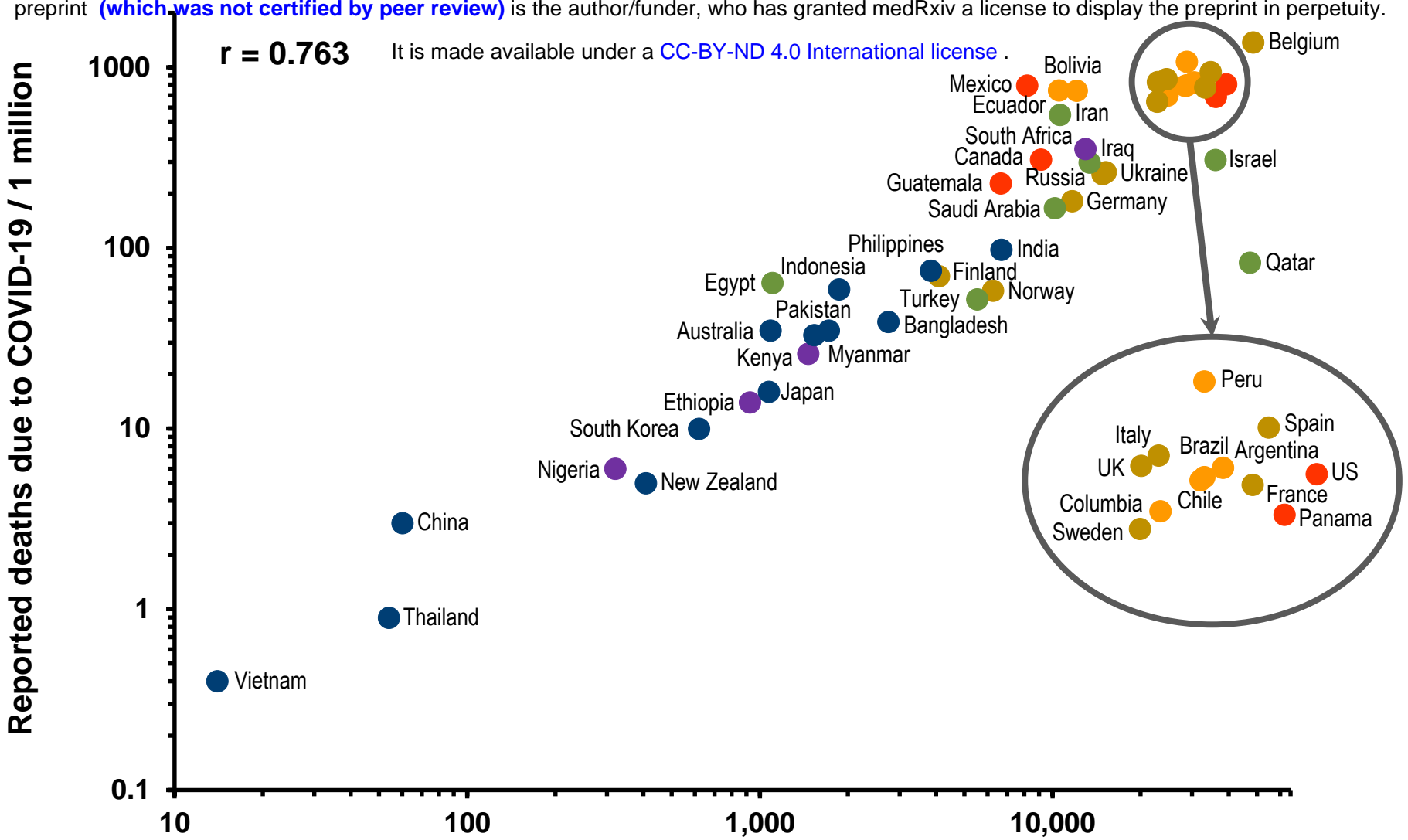

B

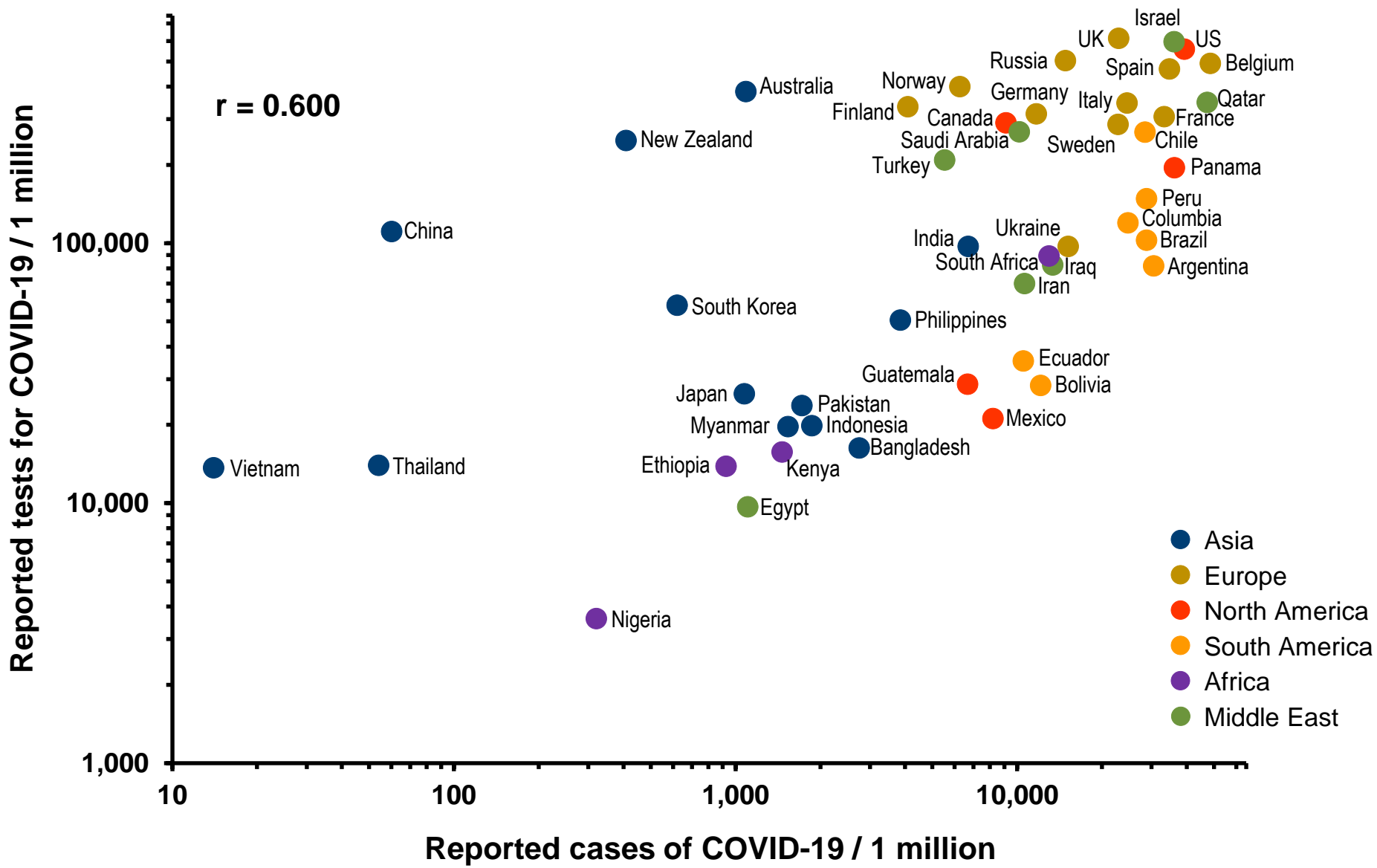

FIGURE 2 COVID-19 fatality and testing rates relative to case rates world-wide as of November 25, 2020. The reported cases of COVID-19 per 1 million people are presented by country versus the reported deaths due to COVID-19 (Panel A) and versus the confirmed tests for COVID-19 (Panel B). Blue circles represent Asia; gold circles, Europe; red circles, North America; orange circles, South America, purple circles, Africa; and green circles, the Middle East. Log scales were used. UK, United Kingdom, US, United States. 